\title{
Carbon Stock of Luvisols as Influenced by Cropping System of Abela Lida, Southern Ethiopia
}

\author{
Teshome Yitbarek* \\ Department of Natural Resource Management, Wolkite University, Ethiopia
}

Submission: April 16, 2019; Published: May 06, 2019

*Corresponding author: Teshome Yitbarek, Department of Natural Resource Management, Wolkite University, P.O. Box 7, Ethiopia

\begin{abstract}
Assessing and quantifying carbon stock by taking into consideration the type of land use and soil type would have great contribution for an appropriate land use decision and sustainable carbon soil stock management. The purpose of this study was to examine the influence of cropping systems on carbon stock of Luvisols of Abela Lida, Southern Ethiopia. Three representative adjacent cropping systems (enset, coffee and maizeharicot bean intercropping) were considered for the study. The mean values of soil organic carbon (SOC) ranged from 1.72 to $2.75 \%$, medium to high status, respectively. The highest mean value of SOC (2.75\%) was recorded in soils under coffee. In the other hand, the lowest mean value $(1.72 \%)$ of SOC was recorded under the soils of maize-haricot bean intercropping. The results of the study showed significant difference (P $\leq 0.05)$ in soil organic carbon stock under the different cropping systems. Soil under coffee cropping systems had significantly higher values of SOCst (51.01.9Mg ha-1) than enset and maize-haricot bean intercropping (46.61 and 34.58Mg ha-1, respectively). It could be concluded that cropping systems have significant influence on soil organic carbon status and carbon stocks of the soils of an area. Therefore, it is important and advisable to consider cropping systems of a given area for soil management to optimize organic carbon status and carbon stock in a sustainable manner.

Keywords: Land use; Organic carbon; Soil management
\end{abstract}

\section{Introduction}

Carbon exists as inseparable components of biomass and soil organic matter. Its storage in soil organic matter is important in mitigating global climate change and improves the livelihood of resource- poor farmers [1]. Soil organic carbon represents a key indicator for soil quality [2], both for agricultural functions (production and economy), especially for resilience and sustainability of agriculture and for environmental functions (carbon sequestration and air quality)[3]. Due to these facts, carbon stocks have received considerable attention in the recent past [4].

Soil organic carbon (SOC) plays an important role in the global carbon (C) cycle. Soils have the potential to sequester carbon from the atmosphere with proper management [5]. It is generally assumed that soils are the largest $\mathrm{C}$ sinks in terrestrial ecosystems [6] with $\mathrm{C}$ stock of ( 1500Pg), which approximately twice the amount held in the atmosphere and three times the amount contained in terrestrial vegetation [7]. In the other hand, the global emission of soil carbon dioxide is well recognized as one of the largest contributors to worldwide carbon fluxes [8]. Therefore, increasing attention has been paid to soil carbon sequestration over recent decades [9].

Carbon stock of an area could be influenced by land use, soil type and soil management practices. The amount of carbon in any soil is a function of the soil forming factors including climate, relief, organisms, parent material, and time. Over the centuries, humans, usually included as part of the "organisms" factor, have profoundly influenced the dynamics and sequestration of carbon in soils by their land use and management practices $[10,11]$. Generally, the type of land use system is an important factor that controls SOC levels $[12,13]$. Therefore, assessing and quantifying carbon stock by taking into consideration the type of land use and soil type would have great contribution for an appropriate land use decision and sustainable carbon soil stock management for the study area, where there is little information in this regard. It has also been suggested that monitoring the effect of land use on soil quality attributes within an ecosystem can provide a useful way to control land degradation and achievement of sustainable management [11]. Moreover, in order to estimate the change in the $\mathrm{C}$ stocks of soils, it is first necessary to establish baseline data [14].

\section{Materials and Methods}

\section{Description of the study area}

The study was conducted at Abela Lida, mid altitude parts of Shebedino district of Sidama zone in southern region of Ethiopia. It has an altitude of 1877 masl with a bimodal rainfall pattern, 
where the short rain falls from mid-February to April and the long rain fall during the period of June to September. The mean annual precipitation ranges between $1200-2500 \mathrm{~mm}$ and mean annual temperature ranges $12-20^{\circ} \mathrm{C}[15]$.

The soil type of the study area is Chromic Luvisols [16] and it is locally characterized as Shakado, Kakacha and Dora. The base for their classification is the fertility status of the soils. Shakado soils are found near the farmers' house, which developed through the continuous application of organic manure and house refuses, and have deep top soils of very dark brown color. The soil is friable and very easy to manipulate. This type of soil is mainly planted enset and coffee along with high value fruits and vegetables. Kakacha soils are less fertile than Shakado. They are found at some distance from the homestead and seldom received manure and used mainly to maize-haricot bean cropping. Dora soils, on the other hand are characterized as the least fertile soils of the area and very small area support coffee plantation, although the trees give production once in two years.

Major crops grown in the study area are enset, coffee, maize and haricot bean. The enset and coffee are traditional component of the farming system of the area. From fruits and vegetable, avocado, banana, orange, papaya and sugar cane are common in the area.

\section{Soil sampling and analysis}

Three representative adjacent cropping systems (enset, coffee and maiz-haricot bean intercropping) were considered for the study. In each cropping system, four composite soil samples were taken by thoroughly mixing forty subsamples that had been taken randomly in three replications within 0 to $20 \mathrm{~cm}$ depth. Twelve undisturbed samples were also collected with core sampler for determination of bulk density. The samples were air-dried, ground with mortar and pestle to pass through $2 \mathrm{~mm}$ sieve.

Bulk densities were determined by core sampling [17]. Particle size distribution was determined by Bouyoucos hydrometer method [18]. Soil pH was measured using a 1:2.5 soil to water ratio [19], whereas OC was determined by wet digestion method [20].

The soil organic carbon stock of the different cropping systems was estimated with the following equation [21]:

$$
\text { SOCst }=\frac{S O C}{100} * B D^{*} D * 100
$$

Where: SOCst is soil organic carbon stock ( $\left.\mathrm{Mg} \mathrm{C} \mathrm{ha}^{-1}\right)$; SOC the soil organic carbon concentration (\%); BD is the bulk density $\left(\mathrm{gcm}^{-3}\right)$; D is the depth $(\mathrm{cm})$; multiplied by 100 to convert from $\mathrm{g}$ $\mathrm{C} \mathrm{cm}^{-2}$ to $\mathrm{Mg} \mathrm{C} \mathrm{ha-1}$.

\section{Statistical analysis}

The analysis of variance (ANOVA) was performed using General Linear Model (GLM) procedure [22] version 9.2. Mean separation was carried out using LSD at $\mathrm{P}<0.05$.

\section{Results and Discussion}

\section{Selected soil physical and chemical properties of the study area}

The selected soil physical and chemical properties of the study area are presented in Table 1 . The textural class of the study area was loam, irrespective of the cropping systems. Texture as an inherent characteristic of the soils does not easily influence by cropping system and soil fertility management. The highest (29.08\%) mean value of clay was obtained from maize-haricot bean cropping system, whereas relatively the lowest (24.07\%) mean value of clay was recorded under enset cropping system. In previous study, it was stated that highest clay content of soils was recorded under maize and the suggested reason was due to accelerated weathering as the result of disturbance caused by continuous cultivation as compared to enset and coffee cropping systems that have minimum disturbance [23]. The highest $(40.65 \%)$ mean value of silt was recorded under enset, while the lowest (36.64\%) was obtained under maize-haricot bean intercropping. With respect to sand, the highest (39.01\%) mean value was recorded under coffee cropping system.

Table 1: Mean values of selected soil physical and chemical properties under different cropping systems.

\begin{tabular}{|c|c|c|c|c|c|c|}
\hline \multirow{2}{*}{ Cropping System } & \multicolumn{3}{|c|}{ Particle Size Distribution (\%) } & \multirow{2}{*}{ Textural Class } & \multirow{2}{*}{ Bulk Density (gm $\left.\mathbf{~ c m}^{-3}\right)$} & \multirow{2}{*}{$\mathbf{p H}$} \\
\cline { 2 - 6 } & Clay & Silt & Sand & & 0.96 \\
\hline Enset & 24.07 & 40.65 & 35.28 & Loam & 7.59 \\
\hline Coffee & 21.62 & 39.37 & 39.01 & Loam & 0.93 & 6.52 \\
\hline Maize-Haricot Bean & 29.08 & 36.64 & 34.28 & Loam & 1.02 & 6.31 \\
\hline
\end{tabular}

The mean values for bulk density of surface soils $(0-20 \mathrm{~cm})$ of the considered cropping systems ranged from $0.931 .02 \mathrm{gm} /$ $\mathrm{cm}^{3}$ (Table 1). The result of the study agrees with Brady and Weil [24], who indicated that the range of bulk density between 0.8 and $1.2 \mathrm{~g} / \mathrm{cm}^{3}$ is a typical characteristic of loamy A horizon. The bulk density values of the soils under enset and coffee cropping systems are relatively lower as compared to that of maizeharicot bean intercropping. The reasons for relatively lower bulk density in the case of enset and coffee cropping systems might be intensive manure application, decomposition of fallen leaves, left over of harvesting and processing. [24,25] stated that dung decomposition plays a role in reducing surface compaction by increasing the volume of soils macro-pores. On the other hand, relatively the highest bulk density value was under maize-haricot bean intercropping, which might be due to the low levels of organic matter and compaction effect as a result of continuous 
tillage activities. These soils did not receive application of manure and there has been complete removal of crop residues from the fields for different purposes.

The mean soil $\mathrm{pH}$ values of the considered cropping systems ranged from 6.31 to 7.59. The highest mean soil $\mathrm{pH}$ value (7.59) recorded in soils under enset, which might be due to the relatively high amount of manure application. Previous study confirmed that the application of farmyard manure led to higher soil $\mathrm{pH}[26,27]$. Moreover, decomposition of the large enset leaves biomass, left over of harvesting and processing enrich exchangeable bases that are responsible for high soil $\mathrm{pH}$ values. The mean $\mathrm{pH}$ value (6.52) under coffee was relatively low, basic cations removal due to harvesting might be the reason. Heavy cropping coffee over a period of years would reduce level of potassium and the $\mathrm{pH}$ would fall [28]. Relatively the lowest mean value of $\mathrm{pH}$ was recorded under maize-haricot bean. The reason might be due to long-term cultivation and fertilization. The $\mathrm{pH}$ of the surface few centimeters of soil usually decreased rapidly when high rates of nitrogen fertilizers is used [29].

\section{The effluence of cropping system on carbon stock of Luvisols}

The mean values of soil organic carbon (SOC) ranged from 1.72 to $2.75 \%$ (Table 2), medium to high status respectively [30]. The highest mean value of SOC $(2.75 \%)$ was recorded in soils under coffee, which might be due to the decomposition of fallen leaves of shade trees and grasses. Generally, the mean values of SOC were high in coffee and enset cropping systems. The application of manure and decomposition of fallen leaves might be the reason. The no tillage practices of the farmers in these cropping systems may also contribute these values. Long term no tillage systems protect SOC through formation of stable sand and silt sized particles [31]. It was reported that SOC was significantly higher in the upper 0 to $5 \mathrm{~cm}$ depth under no tillage farm [32]. The lowest mean value $(1.72 \%)$ SOC was recorded under the soils of maize-haricot bean intercropping. The reason could be continuous oxidation of organic matter due to intensive cultivation and complete crop residue removal for different purposes. Tillage practices can alter the distribution of SOC. Several studies under varies soils and climate conditions have shown the impact of tillage on SOC [33].

Table 2: Influence of cropping systems on carbon stock of Luvisols.

\begin{tabular}{|c|c|c|}
\hline Cropping System & SOC (\%)1 & SOCst $\left(\mathbf{M g ~ h a}^{-\mathbf{1}}\right)^{\mathbf{2}}$ \\
\hline Enset & 2.44 & $46.61 \mathrm{~b}$ \\
\hline Coffee & 2.75 & $51.01 \mathrm{a}$ \\
\hline Maize-Haricot Bean & 1.72 & $34.58 \mathrm{c}$ \\
\hline LSD (0.05) & & 3.25 \\
\hline CV (\%) & & 4.61 \\
\hline
\end{tabular}

The mean values of soil organic carbon stock (SOCts) of the copping systems ranged between 34.58 to $51.01 \mathrm{Mg}$ ha- 1 within 0 to $20 \mathrm{~cm}$ soil depth. There were significant differences $(\mathrm{p}<0.05)$ in mean values of SOCst among the cropping systems (Table 2). The highest mean value of SOCst (51.01Mg ha-1) was obtained in coffee cropping system. In this cropping system, there was high status of organic matter due to the decomposition of fallen leaves of shed trees and continuous application of manure. In the other hand, the lowest mean value (34.38 Mg ha-1) was obtained in maizeharicot bean intercropping. Comparable result was obtained from cultivated land of Kersa sub watershed, eastern Ethiopia [34]. In this cropping system, the organic matter was depleted duet to continuous cultivation and complete removal of crop residues.

\section{Conclusion}

The findings of this study clearly showed that cropping systems significantly influenced the soil organic carbon contents and carbon stock. The organic content and carbon stock of coffee and enset cropping systems were greater than the maize-haricot bean intercropping. It is therefore important and advisable to consider cropping systems of a given area to optimize organic carbon status and carbon stock of the soils in sustainable manner.

\section{References}

1. Bessah, E, Abdullah, B, Sampson KA. Appollonia AO (2016) Dynamics of soil organic carbon stocks in the Guinea Savanna and transition agroecology under different land-use systems in Ghana. Cogent Geoscience 2: $1-11$.

2. Miralles I, Raú, O, Gonzalo A, Manuel S, Miguel S (2009) Soil quality and organic carbon ratios in mountain agro-ecosystems of South-east Spain. Geoderma 150(1-2): 120-128.

3. Food and Agriculture Organization of the United Nations (2001) Soil carbon sequestration for improved land management, World Soil Resources Reports 96, Rome. p. 58.

4. Sundarapandian SM, Amritha S, Gowsalya L, Kayathri P, Thamizharasi M, et al. (2016) Soil organic carbon stocks in different land uses in Pondicherry University Campus, Puducherry, India. Tropical Plant Research 3(1): 10-17.

5. Daniel K (2015) Carbon sequestration potential on agricultural lands: A review of current science and available practices. National Sustainable Agriculture Coalition Breakthrough Strategies and Solutions LLC 1-36.

6. Munoz-Rojas M, Jordan A, Zavala LM, De la Rosa DS, Abd-Elmabod K, et al. (2012) Organic carbon stocks in Mediterranean soil types under different land uses (Southern Spain). Solid Earth 3: 375-386.

7. Oso V, Rajashekhar Rao BK (2017) Land use conversion in humid tropics influences soil carbon stocks and forms. J Soil Sci Plant Nutr 17(2): 543-553.

8. Mehmood A, Mhammad S, Akhtar SR, Muhammad I, Imran M, et al. (2018) Soil organic carbon stock variation with climate and land use in shale derived soils. J Serb Chem Soc 83(6): 785-793.

9. Qiu L, Zhu J, Wang K, Hu W (2016) Land use changes induced countyscale carbon consequences in Southeast China 1979-2020, Evidence from Fuyang, Zhejiang Province. Sustainability 8(38): 1-13.

10. Wasak K, Drewnik M (2015) Land use effects on soil organic carbon sequestration in calcareous Leptosols in former pastureland - a case study from the Tatra Mountains (Poland). Solid Earth 6(4): 1103-1115.

11. Khormali F, Shamsi S (2014) Effect of land use on the carbon stock and soil quality attributes in loess derived soils in Agh-Su Watershed, Golestan Province, Iran. Environmental Resources Research 2(2): 1-16. 
12. Patil SD, Sen TK, Chatterji S, Sarkar D, Handore RM (2014) Changes in soil organic carbon stock as an effect of land use system in Gondia District of Maharashtra. International journal of Environmental Science 5(2): 372-381.

13. Dengiz O, Sağlam M, Türkme, F (2015) Effects of soil types and land use-land cover on soil organic carbon density at Madendere watershed. Eurasian Journal Soil Science 4(2): 82-87.

14. Choudhary BK, Majumdar K, Datta BK (2016) Effects of land use on the soil organic carbon storage potentiality and edaphic factors in Tripura, Northeast India. American Journal of Climate Change 5(3): 417-429.

15.Zenebe A (2003) Tree species diversity, top soil conditions and arbuscular mycorrhizal association in the Sidama traditional agro-forestry Land use. Southern Ethiopia. Swedish University of Agricultural Sciences pp. 15-18.

16. Teshome Y (2006) Influence of cropping systems on physicochemical properties of soils of Shebedino District, Sidama Zone, Southern Ethiopia. (Unpublished MSc Thesis). Hawassa University, Ethiopia. p. 54.

17. Black GR, Hertge KH (1986) Bulk density. In: A Klute, (Eds.) Methods of Soil Analysis, SSSA, Madison, Wis, USA, pp. 377-382.

18. Bouyoucos GJ (1962) Hydrometer method improvement for making particle size analysis of soils. Agronomy Journal 54(4): 179-186.

19. Sahilemariam S, Taye B (2000) Procedure for soil and plant analysis, National Soil Research Centre, Ethiopian Agricultural Research Organization, Addis Ababa, Ethiopia. p. 86.

20. Walkley A, Black IA (1934) An examination of the degtjareff method for determining soil organic matter, and a proposed modification of the chromic acid titration method. Soil Science 37(1): 29-38.

21. Were KO, Singh BR, Dic OB (2015) Effects of land cover change on soil organic carbon and total nitrogen stocks in the Eastern forest reserve, Kenya. In Sustasinable Intensification of Advanced Food Security and Enhance Climate Resilience in Africa. Springer International Publishing.

22. Statistical Analysis System (SAS) Institute Inc (2008) SAS/STAT 9.2 User's Guide, SAS Institute, Cary, NC, USA

23. Shiferaw B (2003) Soil phosphorus fraction as influence by different cropping systems in Andosols and Nitosols in Kembata Temmbaro and
Wolita Zones. (Unpublished MSc Thesis). Alemaya University, Ethiopia. p. 131 .

24. Brady, N. C. and Weil, R. R. (2002) The Nature and Properties of Soils. Pearson Education, Inc. p. 134-144.

25. Heric JE, Lal R (1995) Soil physical property changes during dung decomposition in a tropical pasture. Soil Sci Soc Am J 59(3): 908-912.

26. Katayama A, Nozawa M, Yamakawa H, Fujie K (1998) Long-term change in microbial community structure in soils subjected to different fertilizing practices revealed by quinone profile analysis. Soil Sci Soc Am J 44: 559-568.

27. Teshome, $T$ (2005) Effect of different organic residues on microbial distribution and physicochemical properties of Nitosols of Gaambella area. (Unpublished MSc Thesis). Alemaya University, Ethiopia. p. 61.

28. Willson KC (2004) Coffee, Cocoa and Tea. CABI Publishing, pp. 300.

29. Ismail I, Blevins RL, Frye WW (1994) Long-term no-tillage effects on soil properties and continuous corn yields. Soil Sci Soc Am J 58(1): 193198.

30. Tadese T (1991) Soil, plant, water, fertilizer, animal manure and compost analysis. International Livestock Research Center for Africa, Addis Ababa, Ethiopia. Working Document 13.

31. Carlos J, Cerri C, Dick WA, Lal R, Venske SP, et al. (2000) Organic matter dynamics and carbon sequestration rates for tillage chronosequences in a Brazilian Oxisols. Soil Sci Soc Am J 65(5): 1486-1498.

32. Follett RF, Peterson GA (1988) Surface soil Nutrient distribution as affected by wheat-fallow tillage systems. Soil Sci Soc Am J 52(1): 141 147.

33. Wanniarachi SD, Vorone, RP, Beyaert RP, Manchezie AF (1999) Tillage effects on the dynamics of total and corn residue derived soil organic matter in two southern Ontario Soils. Canadian Journal of Soil Science 79(3): 473-479.

34. Yared M, Kibebew K, Bobe B, Muktar M (2018) Soil organic carbon stock under different land use types in Kersa Sub Watershed, Eastern Ethiopia. African Journal of Agricultural Research 13(24): 1248-1256.

\section{Your next submission with Juniper Publishers will reach you the below assets}

- Quality Editorial service

- Swift Peer Review

- Reprints availability

- E-prints Service

- Manuscript Podcast for convenient understanding

- Global attainment for your research

- Manuscript accessibility in different formats ( Pdf, E-pub, Full Text, Audio)

- Unceasing customer service

Track the below URL for one-step submission https://juniperpublishers.com/online-submission.php 